Yu. Korsak ${ }^{1}$ D, L. Nykytiuk2 iD

${ }^{1}$ Nuclear Radiology Department, S. Kukura Hospital with Policlinics, Michailovce, Slovakia

2 Uzhhorod National University, Uzhhorod, Ukraine

\title{
Diagnosis, clinical importance and management of thyroid nodules
}

For citation: Mižnarodnij endokrinologǐčnij žurnal. 2021;17(2):155-159. doi: 10.22141/2224-0721.17.2.2021.230570

\begin{abstract}
A thyroid nodule is a discrete lesion within the thyroid gland that is radiologically distinct from the surrounding thyroid parenchyma. Thyroid nodules are prevalent in up to $68 \%$ of randomly selected individuals in whom high resolution ultrasound is performed. The majority of nodules are benign. Thyroid nodules are the clinical manifestation of a myriad of pathologic processes. The use of ultrasound has dramatically reduced the number of patients who undergo surgery for nodules. Several risk scoring systems have been developed which aim to reduce interobserver variability and allow clinicians to make decisions regarding further workup and follow-up. The most useful of these is the Thyroid Imaging Reporting and Data System (TIRADS) classification. The six tier Bethesda scoring system has reduced variability and increased the ability to clinicians to guide patients with thyroid nodules. There is good correlation between cytology and histopathologic outcomes. A significant proportion of patients will however fall into an indeterminate category. The American Thyroid Association uses a different system based on an estimated risk of malignancy from centers that deal with a high volume of patients with thyroid nodules and malignancy. The availability of molecular markers enhanced with next generation sequencing technology and the expression classifier are added diagnostic aids that can help in management. However, these are not available in many countries and in resource limited settings. A pragmatic approach to the diagnosis of indeterminate nodules includes utilizing pre- and posttest probability, clinical acumen, correlation of ultrasound findings and expert opinion in some settings. Using this approach high risk patients can be appropriately chosen for surgery while relegating patients with lower risk to watchful follow-up.
\end{abstract}

Keywords: thyroid; ultrasound; Bethesda scoring; follicular neoplasm; indeterminate nodule; Thyroid Imaging Reporting and Data System; review

\section{Introduction}

A thyroid nodule is a discrete lesion within the thyroid gland that is radiologically distinct from the surrounding thyroid parenchyma [1]. Thyroid nodules are among the common diseases of the endocrine system, with 3-7\% prevalence by palpation [2]. Goiter affects approximately $15.8 \%$ of the general population and iodine is the main environmental factor that determines goiter prevalence [3]. Palpable thyroid nodules are present in approximately $5 \%$ of women and $1 \%$ of men in iodine sufficient areas [4]. If high-resolution ultrasound (USG) was used, up to $68 \%$ of randomly selected individuals may have nodules - more in women and increasing with age in both sexes [5]. There is a linear increase in the prevalence from almost none at age $15-50 \%$ by the age of 65 years [6]. Thyroid nodules are the clinical manifestation of a myriad of pathologic processes. Nonneoplastic nodules are the result of glandular hyperplasia arising spontaneously or following partial thyroidectomy [7]. Hashimoto's thyroiditis may present with a nodular feel but do not represent an example of true nodule formation. Adenomas are characterized by orderly architecture and few mitoses with no lymphatic or vascular invasion. Necrosis is common in nodules resulting in cyst formation. Nodules are monoclonal and grow slowly reflecting the long time taken

Для кореспонденції: Никитюк Л.А., асистент кафедри внутрішньої медицини, медичний факультет, Ужгородський національний університет, пл. Народна, 1, м. Ужгород, 88000, Україна; e-mail: chutorskaja@ukr.net; контактний тел.: +380505878613

For correspondence: Larisa Nikitiuk, MD, PhD, Assistant at the Department of Internal Medicine, medical faculty, Uzhhorod National University, Narodna sq., 1, Uzhhorod, 88000, Ukraine; e-mail: chutorskaja@ukr.net; contact phone: +380505878613

Full list of authors information is available at the end of the article. 
by thyroid cells to divide. Most nodules are detected incidentally. Symptoms of growth and invasion such as dysphagia dystonia and stridor are rare. Bleeding into the nodule occurs rarely and presents with increase in size pain and tenderness or even transient thyrotoxicosis. The incidence of thyroid cancer is increasing rapidly and currently appears to be the most rapidly increasing malignancy among men and women in the general population [8]. This appears to be a worldwide phenomenon [9]. The clinician's approach to the thyroid nodule over the years is to primarily distinguish the small number of nodules that harbor a malignancy from the majority that do not. At autopsy, up to $30 \%$ of thyroid glands will harbor malignant nodules which are under $1 \mathrm{~cm}$ (microcarcinomas); many but not all of them these will have an indolent course [10]. The approach to the thyroid nodule has been muddled by the lack of standardization of both imaging and cytologic techniques. The availability of high-frequency USG and the development of risk scores that can quantify the risk of thyroid malignancy is a significant advance that has demystified decision-making in thyroid nodules. Several USG features have been identified in multivariate analysis as associated with malignancy, specifically papillary cancer of the thyroid. These include the presence of microcalcifications and nodule hypoechogenicity when compared with strap muscles, irregular margins, shape taller than wide on transverse view, central vascularity [11]. Follicular thyroid cancer has somewhat different features. They are more often iso- or hyperechoic, noncalcified, and regular smooth margins [12]. Some features on USG are associated with a low risk of differentiated thyroid cancer. A spongiform appearance defined as the aggregation of multiple microcystic components in more than $50 \%$ of then nodule is strongly suggestive of a benign nodule [13]. Other USG features include hyperechogenicity, large coarse calcification, peripheral calcifications, puff pastry appearance, and comet tail shadowing.

\section{Thyroid Imaging Reporting and Data System (TIRADS) classification}

Several risk scoring systems have been developed which aim to reduce interobserver variability and allow clinicians to make decisions regarding further workup and follow-up. The most useful of these is the Thyroid Imaging Reporting and Data System (TIRADS) classification. Similar to the Breast Imaging-Reporting and Data System for breast lesion, the TIRADS system allows the user understand and explain to the patient the risk of malignancy in a nodule and the need for further workup including aspiration [14]. The TIRADS system correlates exceptionally well with the Bethesda system for cytology [15]. The American Thyroid Association uses a different system based on an estimated risk of malignancy from centers that deal with a high volume of patients with thyroid nodules and malignancy [1]. There is a significant correlation between both systems. However, some nodules that do not meet the criteria for malignancy in the American Thyroid Association guidelines appeared have increased risk of malignancy (18.2\%) [16].
USG-guided cytology and the standardization of interpretation of thyroid cytology has reduced ambiguity. The diagnostic groups reported under the six-tiered Bethesda system for reporting thyroid cytopathology have gained widespread acceptance [17]. Several factors contribute to nondiagnostic specimens including nodule component and the fine-needle aspiration cytology (FNAC) technique. Adequate specimens are categorized as benign, malignant, or indeterminate with the latter being divided into three specific categories each correlating with a different malignancy risk. These include atypia of undetermined significance, follicular or Hürthle cell neoplasms, and suspicious for malignancy [18]. 2-3\% of benign nodules as determined by FNAC will subsequently prove to be malignant [19]. Conversely, the same number of malignant nodules on FNAC will prove to be benign [20]. Large studies showed a high degree of concordance between the system and pathology, especially in the definitively benign and the definitively malignant categories with variability in the intermediate categories.

The indeterminate thyroid nodule will be defined as those nodules that have after an initial evaluation (history, physical examination, ultrasound, and FNAC) have received Bethesda classification of either III, IV, or $\mathrm{V}$ (BIII, BIV, and BV). This indeterminate category falls into a malignancy risk between $5 \%$ and $75 \%$ and represents up to $40 \%$ of all FNACs. Cytologically indeterminate thyroid nodules are associated with a broad range (5-75\%) of malignant risk and accurately informing definitive management poses a challenge. Advancements in molecular testing of fine-needle aspiration biopsies have improved preoperative diagnostic accuracy and prognostication. For indeterminate nodules, such testing ideally will reduce the need for surgery for benign nodules and potentially guide appropriate extent of initial surgery for malignancy [21].

The association of gene mutations and translocation fusions with thyroid cancer has been described extensively [22]. Over the years, several markers of malignancy have been evaluated. Many of the early markers were suboptimal for clinical use. Panels of markers have been developed to improve efficiency and accuracy and commercialized. The Afirma Gene Expression Classifier (GEC) (Veracyte, Inc., South San Francisco, California, USA) uses microarray technology to analyze mRNA expression of 167 different genes, 142 of which are commonly, and 25 which are uncommonly seen with thyroid cancer. Only BIII and BIV are accepted for analysis and generate two possible results, benign and suspicious. In the BIII and BIV setting, the GEC has negative predictive value (NPV) of 95 and $94 \%$, respectively. In the BV category, the NPV was only $85 \%$ [23]. The PPV in BIV and BV are low at 38 and $37 \%$, respectively, reaffirming the role of this test as a rule out (benign) than a rule in test. The usefulness of this test is largely determined by the institutional prevalence of malignancy in nodules [24] and appears to be most useful in a practice setting with the prevalence of malignancy in indeterminate lesions of $15-21 \%$. 
The BIII describes a group of FNAC specimens that contain cells with architectural or nuclear atypia that would not qualify it for BII but does not contain enough suspicious features that would warrant a higher-class assignment. This category was intended for limited use and expected to have a frequency of about $7 \%$. Usage of this category by cytologists has been variable with studies reporting usage up to $27 \%$. When patients in this category underwent surgery, malignancy was seen up to $14.5 \%$ [25]. Using USG features to estimate malignancy, risk in BIII lesions has been examined. The reported cancer risk in BIII lesions and high suspicion sonographic features was between 90 and $100 \%$. The prevalence of at least one suspicious feature on USG in BIII lesions ranged from 18 to $50 \%$ and increased the risk of malignancy to 60-90\% [26]. The overall malignancy rate in these studies was $40-45 \%$.

Fludeoxyglucose-positron emission tomography (FDGPET) has been reported to have a high NPV when applied to the diagnosis of cytologically indeterminate thyroid nodules. In a systematic review and meta-analysis of six studies, FDG-PET had a low positive predictive value (PPV) (39\%) and a high NPV (96\%), when performed in thyroid nodules with BIII or BIV cytology [27]. Since there is significant interobserver variability in this category [28], one recommended approach is to obtain a second opinion from a high volume cytopathologist. Central cytopathologists from institutions with high volume make fewer indeterminate diagnosis (55 vs. $42 \%$ ) than community-based cytopathologists [28]. In one study, a second opinion for a nodule originally read as indeterminate and subsequently reclassified as benign had an NPV $95 \%$. The second opinion improves diagnostic accuracy from 60 to $74 \%$ and avoids diagnostic surgery in $25 \%$ of patients.

A repeat FNA may reclassify the lesion into a more definitive diagnosis. Malignancy rates are similar with single BIII and two successive BIII diagnoses. This approach has been recently questioned. Recent retrospective studies confirm this high NPV though this may be lower in community-based hospital settings [29]. A composite of clinical ultrasound and cytology and patient preference may be used to decide if surgery is required when molecular testing is not available [30].

Secondary Neoplasm/Suspicious for Follicular Neoplasm (Bethesda IV) consists of either arrangement of follicular cells with cell crowding and microfollicle formation and lacking nuclear features of papillary thyroid carcinoma or almost exclusively of Hürthle (oncocytic cells) [31]. The majority of tumors are benign follicular adenomas driven by the oncogenic RAS mutation with uncertain malignant potential. The risk for malignancy is intermediate (15-30\%). The application of this category has provided a mean prevalence of $10 \%(1-25 \%)$ and mean cancer risk of $26 \%$ (14-33\%). Traditionally, diagnostic excision has been used in this category. Molecular markers have added considerably to the diagnostic assessment in this category [32]. Patients with BIV cytology may be followed without surgery. Exceptions include populations with unusual prevalence of malignancy or high pretest probability of disease including family history high-risk sonographic features or prior irradiation. In the presence of these features, the pretest probability will often exceed $50 \%$ reducing the NPV to $<90 \%$; this would be considered too low to avoid diagnostic thyroidectomy [32].

Aspirates with cytologic features that raise a strong suspicion of malignancy but insufficient for conclusive diagnosis are assigned BV. Approximately $1-6 \%$ of patients are assigned to this category and at an average $75 \%$ of patients have malignancy diagnosed at surgery. The pretest probability of disease is high necessitating surgery in patients with this category. Mutational testing has high specificity with low sensitivity. The seven-panel gene of mutations is associated with a PPV of $80-95 \%$ and an NPV of 72-75\% [33]. Conceivably, a positive test may help plan the extent of surgery; a negative test does not obviate the need for one.

\section{Conclusions}

Decision-making in thyroid nodules has significantly improved because of processes available [34], including collaborative work between the endocrinologist, sonologist, cytologist, and surgeon, high-resolution ultrasound, USG-guided FNAC, and on the spot testing for adequacy. The consistent use of ultrasound- and cytology-based scoring systems has greatly reduced uncertainty. The use of clinical data that assesses the risk of malignancy coupled with adequate knowledge of the prevalence malignancy in the population, use of sonographic features in conjunction with the Bethesda scoring system allows for informed decision-making in thyroid nodule.

\section{References}

1. Haugen BR, Alexander EK, Bible KC, et al. 2015 American Thyroid Association Management Guidelines for Adult Patients with Thyroid Nodules and Differentiated Thyroid Cancer: The American Thyroid Association Guidelines Task Force on Thyroid Nodules and Differentiated Thyroid Cancer. Thyroid. 2016 Jan;26(1):1-133. doi:10.1089/thy.2015.0020.

2. Jiang H, Tian Y, Yan W, et al. The Prevalence of Thyroid Nodules and an Analysis of Related Lifestyle Factors in Beijing Communities. Int J Environ Res Public Health. 2016 Apr 22;13(4):442. doi:10.3390/ijerph13040442.

3. Dauksiene D, Petkeviciene J, Klumbiene J, et al. Factors Associated with the Prevalence of Thyroid Nodules and Goiter in Middle-Aged Euthyroid Subjects. Int J Endocrinol. 2017;2017:8401518. doi:10.1155/2017/8401518.

4. Song J, Zou SR, Guo CY, et al. Prevalence of Thyroid Nodules and Its Relationship with Iodine Status in Shanghai: a Population-based Study. Biomed Environ Sci. 2016 Jun;29(6):398407. doi:10.3967/bes2016.052.

5. Bojunga J. Ultrasound of Thyroid Nodules. Ultraschall Med. 2018 Oct;39(5):488-511. doi:10.1055/a-0659-2350. (in German).

6. Li F, Pan D, Wu Y, et al. Ultrasound characteristics of thyroid nodules facilitate interpretation of the malignant risk of Bethesda system III/IV thyroid nodules and inform thera- 
peutic schedule. Diagn Cytopathol. 2019 Sep;47(9):881-889. doi:10.1002/dc.24248.

7. Liang XW, Cai YY, Yu JS, Liao JY, Chen ZY. Update on thyroid ultrasound: a narrative review from diagnostic criteria to artificial intelligence techniques. Chin Med J (Engl). 2019 Aug 20;132(16):1974-1982. doi:10.1097/CM9.0000000000000346.

8. Olson E, Wintheiser G, Wolfe KM, Droessler J, Silberstein PT. Epidemiology of Thyroid Cancer: A Review of the National Cancer Database, 2000-2013. Cureus. 2019 Feb 24;11(2):e4127. doi:10.7759/cureus.4127.

9. Du L, Wang Y, Sun X, et al. Thyroid cancer: trends in incidence, mortality and clinical-pathological patterns in Zhejiang Province, Southeast China. BMC Cancer. 2018 Mar 15;18(1):291. doi:10.1186/s12885-018-4081-7.

10. Wang TS, Goffredo P, Sosa JA, Roman SA. Papillary thyroid microcarcinoma: an over-treated malignancy? World $J$ Surg. 2014 Sep;38(9):2297-303. doi:10.1007/s00268-014-26023.

11. Abdullah MI, Junit SM, Ng KL, Jayapalan JJ, Karikalan B, Hashim OH. Papillary Thyroid Cancer: Genetic Alterations and Molecular Biomarker Investigations. Int J Med Sci. 2019 Feb 28;16(3):450-460. doi:10.7150/ijms. 29935.

12. Podda M, Saba A, Porru F, Reccia I, Pisanu A. Follicular thyroid carcinoma: differences in clinical relevance between minimally invasive and widely invasive tumors. World J Surg Oncol. 2015 Jun 4;13:193. doi:10.1186/s12957-015-0612-8.

13. Hahn SY, Shin JH, Oh YL, Kim TH, Lim Y, Choi JS. Role of Ultrasound in Predicting Tumor Invasiveness in Follicular Variant of Papillary Thyroid Carcinoma. Thyroid. 2017 Sep;27(9):1177-1184. doi:10.1089/thy.2016.0677.

14. Horvath E, Silva CF, Majlis $S$, et al. Prospective validation of the ultrasound based TIRADS (Thyroid Imaging Reporting And Data System) classification: results in surgically resected thyroid nodules. Eur Radiol. 2017 Jun;27(6):2619-2628. doi:10.1007/s00330-016-4605-y.

15. Periakaruppan $G$, Seshadri KG, Vignesh Krishna GM, Mandava R, Sai VPM, Rajendiran S. Correlation between Ultrasound-based TIRADS and Bethesda System for Reporting Thyroid-cytopathology: 2-year Experience at a Tertiary Care Center in India. Indian J Endocrinol Metab. 2018 SepOct;22(5):651-655. doi:10.4103/ijem.IJEM_27_18.

16. Yoon JH, Lee HS, Kim EK, Moon HJ, Kwak JY. Malignancy Risk Stratification of Thyroid Nodules: Comparison between the Thyroid Imaging Reporting and Data System and the 2014 American Thyroid Association Management Guidelines. Radiology. 2016 Mar;278(3):917-24. doi:10.1148/radiol.2015150056.

17. Baloch ZW, LiVolsi VA, Asa SL, et al. Diagnostic terminology and morphologic criteria for cytologic diagnosis of thyroid lesions: a synopsis of the National Cancer Institute Thyroid Fine-Needle Aspiration State of the Science Conference. Diagn Cytopathol. 2008 Jun;36(6):425-37. doi:10.1002/dc.20830.

18. Ahmadi S, Stang M, Jiang XS, Sosa JA. Hürthle cell carcinoma: current perspectives. Onco Targets Ther. 2016 Nov 7;9:6873-6884. doi:10.2147/OTT.S119980.

19. Teixeira GV, Chikota H, Teixeira T, Manfro G, Pai SI, Tufano RP. Incidence of malignancy in thyroid nodules determined to be follicular lesions of undetermined significance on fine-needle aspiration. World J Surg. 2012 Jan;36(1):69-74. doi:10.1007/s00268-011-1336-8.

20. Jena A, Patnayak R, Prakash J, Sachan A, Suresh V, Lakshmi AY. Malignancy in solitary thyroid nodule: A clinicoradiopathological evaluation. Indian J Endocrinol Metab. $2015 \mathrm{Jul}$ Aug;19(4):498-503. doi:10.4103/2230-8210.159056.

21. Mitchell J, Yip L. Decision Making in Indeterminate Thyroid Nodules and the Role of Molecular Testing. Surg Clin North Am. 2019 Aug;99(4):587-598. doi:10.1016/j.suc.2019.04.002.

22. Ferrari SM, Fallahi P, Ruffilli I, et al. Molecular testing in the diagnosis of differentiated thyroid carcinomas. Gland Surg. 2018 Aug;7(Suppl 1):S19-S29. doi:10.21037/gs.2017.11.07.

23. Alexander EK, Kennedy GC, Baloch ZW, et al. Preoperative diagnosis of benign thyroid nodules with indeterminate cytology. N Engl J Med. 2012 Aug 23;367(8):705-15. doi:10.1056/ NEJMoa1203208.

24. Marti JL, Avadhani V, Donatelli LA, et al. Wide Inter-institutional Variation in Performance of a Molecular Classifier for Indeterminate Thyroid Nodules. Ann Surg Oncol. 2015 Nov;22(12):3996-4001. doi:10.1245/s10434-015-4486-3.

25. Bongiovanni $M$, Crippa $S$, Baloch Z, et al. Comparison of 5-tiered and 6-tiered diagnostic systems for the reporting of thyroid cytopathology: a multi-institutional study. Cancer Cytopathol. 2012 Apr 25;120(2):117-25. doi:10.1002/cncy.20195.

26. Kim DW, Lee EJ, Jung SJ, Ryu JH, Kim YM. Role of sonographic diagnosis in managing Bethesda class III nodules. AJNR Am J Neuroradiol. 2011 Dec;32(11):2136-41. doi:10.3174/ ajnr.A2686.

27. Ruhlmann M, Ruhlmann J, Görges R, et al. 18F-Fluorodeoxyglucose Positron Emission Tomography/Computed Tomography May Exclude Malignancy in Sonographically Suspicious and Scintigraphically Hypofunctional Thyroid Nodules and Reduce Unnecessary Thyroid Surgeries. Thyroid. 2017 Oct;27(10):1300-1306. doi:10.1089/thy.2017.0026.

28. Cibas ES, Baloch ZW, Fellegara G, et al. A prospective assessment defining the limitations of thyroid nodule pathologic evaluation. Ann Intern Med. 2013 Sep 3;159(5):325-32. doi:10.7326/0003-4819-159-5-201309030-00006.

29. Harrell RM, Bimston DN. Surgical utility of Afirma: effects of high cancer prevalence and oncocytic cell types in patients with indeterminate thyroid cytology. Endocr Pract. 2014 Apr;20(4):364-9. doi:10.4158/EP13330.OR.

30. Alexander EK, Pearce EN, Brent GA, et al. 2017 Guidelines of the American Thyroid Association for the Diagnosis and Management of Thyroid Disease During Pregnancy and the Postpartum. Thyroid. 2017 Mar;27(3):315-389. doi:10.1089/ thy.2016.0457.

31. Agarwal S, Bychkov A, Jung CK, et al. The prevalence and surgical outcomes of Hürthle cell lesions in FNAs of the thyroid: A multi-institutional study in 6 Asian countries. Cancer Cytopathol. 2019 Mar;127(3):181-191. doi:10.1002/cncy.22101.

32. Kargi AY, Bustamante MP, Gulec S. Genomic Profiling of Thyroid Nodules: Current Role for ThyroSeq Next-Generation Sequencing on Clinical Decision-Making. Mol Imaging Radionucl Ther. 2017 Feb 9;26(Suppl 1):24-35. doi:10.4274/2017.26. suppl.04.

33. Frey MK, Kim SH, Bassett RY, et al. Rescreening for genetic mutations using multi-gene panel testing in patients 
who previously underwent non-informative genetic screening. no.2015.08.006.

34. Francis GL, Waguespack SG, Bauer AJ, et al; AmeriAccepted 02.03.2021 can Thyroid Association Guidelines Task Force. Management Guidelines for Children with Thyroid Nodules and Differentiated Thyroid Cancer. Thyroid. 2015 Jul;25(7):716-59. doi:10.1089/ thy.2014.0460.

\section{Information about authors}

Yuriy Korsak, MD, PhD, Ass. prof., Nuclear Radiology Department physician, S. Kukura Hospital with Policlinics Michailovce, a.s. Spitalska, 2, Michailovce, 07101, Slovakia; https://orcid.org/0000-0001-8511-0556. Larisa Nikitiuk, MD, PhD, Assistant at the Department of Internal Medicine, medical faculty, Uzhhorod National University, Narodna sq., 1, Uzhhorod, 88000, Ukraine; e-mail: chutorskaja@ukr.net; contact phone: +380505878613; https://orcid.org/0000-0003-3259-4205.

Conflicts of interests. Authors declare the absence of any conflicts of interests and their own financial interest that might be construed to influence the results or interpretation of their manuscript.

Корсак Ю. 1, Никитюк А.А. ${ }^{2}$

${ }^{1}$ ВіАділення ялерної радіології, лікарня і поліклініка Штефана Кукури, м. Міхаловце, Словаччина

2 Ужгородський національний університет, м. УжгороА, Україна

\section{Аіагностика, кАінічне значення та Аікування вузлів щитопоАібної залози}

Резюме. Огляд літератури присвячений питанням діагностики та лікування вузлів щитоподібної залози (ЩЗ). Вузли ЩЗ виявили у 68 \% випадково відібраних осіб, яким проводилося ультразвукове дослідження (УЗД) високої роздільної здатності. При цьому більшість вузлів мала доброякісний характер. Вузли Щ3 є клінічним проявом багатьох патологічних процесів. Застосування УЗД дозволило різко зменшити число оперативних втручань на ЩЗ з приводу вузлового зоба. Розроблено декілька систем оцінки ризику, спрямованих на поліпшення діагностики вузлового зоба, $з$ подальшою можливістю клініцистів приймати рішення щодо подальшого спостереження за хворими на вузловий зоб. Найкориснішою з них є класифікаційна система TIRADS. Шестирівнева система бальних оцінок Bethesda також надає цінну інформацію клініцистам щодо менеджменту вузлів Щ3. При цьому встановлена кореляція між цитологічними та гістопатологічними результатами. Однак частка пацієнтів потрапляє до так званої невизначеної категорії. Американська тиреоїдна асоціація використовує систему, що грунтується на оціночному ризику малігнізації вузлів Щз. Наявність молекулярних маркерів вдосконаленої технології найновішого покоління з класифікацією експресії належить до сучасних додаткових діагностичних методів, що можуть сприяти успішному менеджменту тиреоїдних вузлів. Водночас ці методи є недоступними в багатьох країнах. Прагматичний підхід до діагностики таких вузлів містить використання комплексного підходу клініцистів, фахівців з УЗД, цитологів. При використанні цього підходу пацієнтів з високим ризиком можна належним чином відібрати для подальшого хірургічного лікування, а за пацієнтами з меншим ризиком здійснювати динамічне спостереження.

Ключові слова: щитоподібна залоза; ультразвукове дослідження; Bethesda scoring; вузлові утворення; Thyroid Imaging Reporting and Data System; огляд 